Religare, ISSN: 19826605, v.16, n.2, dezembro de 2019, p.461-493.

\title{
Etnografando um grupo religioso inclusivo: reflexões metodológicas e o ser afetado ${ }^{1}$.
}

\author{
Ethnographing of one religous inclusive group: metodological \\ reflexions and the being affected
}

Arielson Teixeira do Carmo ${ }^{2}$

\section{Resumo}

No período de 25 de maio de 2017 a 11 de novembro de 2018 realizei uma pesquisa de cunho etnográfica junto a um grupo religioso destinado ao público LGBT na cidade de Pelotas, RS - conhecido como Comunidade Cristã Nova Esperança Internacional (CCNEI). A CCNEI, com sede oficial localizada no Estado de São Paulo é uma instituição religiosa que se autodenomina inclusiva fundada em 8 de agosto de 2004 e tem como principal proposta a aceitação da diversidade sexual (principalmente de pessoas LGBTs) em seus espaços de culto ao sagrado. Dessa maneira, meu principal objetivo com esse artigo é discutir sobre o método de investigação adotado, que além da etnografia, contou com observação participante e entrevistas semiestruturadas. Revelo ainda ao leitor minhas percepções, experiências, emoções vividas em campo e as formas de como fui afetado durante a realização da pesquisa. Trazer essas discussões permitirão que o leitor perceba as eventuais sensações e impressões pelas quais passam o pesquisador no desenvolvimento de uma pesquisa sociológica de cunho etnográfica e sua importância para revelar problemas microsociais específicos, relações de interações e particularidades de grupos e pessoas.

Palavras-chaves: Etnografia Sociológica; vivências; ser afetado; Grupo Religioso Inclusivo; LGBT.

\section{Abstract}

From May 25, 2017 to November 11, 2018, I conducted an ethnographic survey of a religious group for the LGBT public in the city of Pelotas, RS - known as Comunidade Cristã Nova Esperança Internacional (CCNEI). CCNEI, headquartered in the state of São Paulo, is a self-described inclusive religious institution founded on August 8, 2004 and its main goal is the acceptance of sexual diversity (especially of LGBT people) in its sacred worship spaces. Thus, my main objective with this article is to discuss the

\footnotetext{
1 Este artigo é parte das reflexões que realizei na minha dissertação de mestrado intitulada "RITUAIS, TRAJETÓRIAS RELIGIOSAS E HOMOSSEXUALIDADE NA CIDADE DE PELOTAS, RS". Financiada pela CAPES (Coordenação de Aperfeiçoamento de Pessoal de Nível Superior). Defendida no Programa de Pós-graduação em Sociologia na Universidade Federal de Pelotas (UFPel).

2 Cientista Social. Mestre em sociologia pela Universidade Federal de Pelotas. Doutorando em Sociologia na Universidade Federal de Pelotas (UFPel).
} 
research method adopted which in addition to ethnography, employed participant observation and semi-structured interviews. I also reveal to the reader my perceptions, experiences, emotions lived in the field and the ways in which I was affected during the research. Bringing these discussions will allow the reader to perceive the possible sensations and impressions that the researcher goes through in the development of an ethnographic sociological research and its importance to reveal specific microsocial problems, interaction relations and particularities of groups and people.

Keywords: Sociological Ethnography; experiences; being affected; Inclusive Religious Group; LGBT

\section{INTRODUÇÃO}

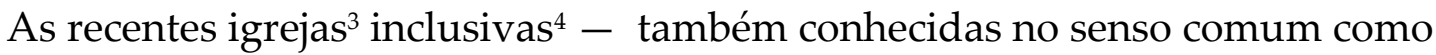
igrejas gays 5 são grupos religiosos que possuem como principal objetivo atender às demandas religiosas de um público específico - o público LGBT6 (Lésbicas, Gays, Bissexuais, Travestis, Transexuais e Transgêneros) cristão. Cabe, entretanto, frisar que

\footnotetext{
${ }^{3}$ Considero importante situar o leitor que as categorias de igreja e célula religiosa serão acionadas aqui a partir de uma visão durkheimiana. Assim, compreendo igreja como sendo: “Uma sociedade cujos membros estão unidos por se representarem da mesma maneira o mundo sagrado e por traduzirem essa representação comum em práticas idênticas, é isso a que chamamos de uma igreja" (DURKHEIM, 2003, p. 28).

${ }^{4} \mathrm{O}$ termo "inclusivo" pode ser problematizado no campo das representações por sua ligação com aquilo que está à margem, como os deficientes físicos e mentais (questão mais conhecida no campo do senso comum como "educação inclusiva"), com a população carcerária, o que marca o termo de forma a dar conta de "corpos abjetos" no sentido que Judith Butler (2003) nos propõe. O inclusivo, assim, acabaria por corroborar os discursos que colocam sexualidades e corpos não heterossexuais e não normativos à margem da religião e da sociedade ou alertaria para uma necessária legitimação de muitas existências que a normatividade mantém "abjetas". É interessante perceber que as igrejas que se afirmam "inclusivas", - embora sejam direcionadas a uma perspectiva de inclusão e aceitação da homossexualidade como perfeitamente compatível com uma religiosidade cristã expressa por elas -, não são exclusivamente para homossexuais, estando abertas a todas as pessoas, incluindo, assim, heterossexuais (Cf: WEISS DE JESUS, 2012, p. 66-67).

${ }^{5}$ É importante esclarecer que muitas dessas denominações não se reconhecem enquanto igrejas para gays, preferem ser chamadas de igrejas LGBTs ou mesmo "inclusivas" pois nos discursos de muitas delas a igreja não é destinada único e exclusivamente para homossexuais do sexo masculino, mas para todas as pessoas, igrejas que acolhem as diversidades, que estão abertas para todas as pessoas (MUSSKOPF, 2008).

${ }^{6}$ Adotei esta sigla por ser a mais usada por órgãos governamentais e movimentos sociais, ao invés, da sigla mais recente LGBTQI+ (Lésbicas, Gays, Bissexuais, Travestis, Transexuais, Transgêneros, Estudo Queer e Intersex).
} 
Religare, ISSN: 19826605, v.16, n.2, dezembro de 2019, p.461-493.

muitas dessas igrejas não se restringem apenas ao público $\mathrm{LGBT}^{7}$, se estende também ao público, em geral, podendo também ser frequentadas por pessoas heterossexuais. As igrejas com propostas inclusivas surgem nos Estados Unidos na década de 1960 e existem no Brasil há mais de vinte anos. Essas igrejas possuem vertentes distintas e denominações heterogêneas. Existem denominações que se particularizam por serem mais liberais no que concerne à sexualidade de seus fiéis; aquelas que se aproximam e estreitam laços com o ativismo LGBT; as de cunho mais conservador, no que tange às condutas e moralidades dos fiéis - essas muito mais próximas do movimento evangélico pentecostal - e outras que se aproximam de uma vertente mais carismática católica. Apesar dessas distinções, o que essas igrejas possuem em comum é o fato de integrarem um movimento religioso recente que vem resistindo e ganhando visibilidade no cenário religioso brasileiro nas últimas décadas por compactuarem com um discurso de "inclusão" e cidadania religiosa para homossexuais ${ }^{8}$ cristãos.

Nesse sentido, o principal argumento defendido por essas igrejas inclusivas é que, no decorrer da história ocidental cristã (Igrejas Católicas, Protestantes e Evangélicas de posturas conservadoras), consistentemente se utilizaram e utilizam-se formas de excluir e afastar pessoas tidas como desviantes ${ }^{9}$ da orientação sexual socialmente aceita pela sociedade cristã ocidental - a heterossexualidade - bem como as proibiram de vivenciarem e terem acesso aos bens sagrados, materiais e simbólicos cristãos $^{10}$. Nesse contexto, a teologia inclusiva propõe, em certa medida, a

\footnotetext{
7 Como sugere Maranhão (2015) "termo considerado pouco conveniente pela maioria delas visto incluírem pessoas de quaisquer identidades/expressões de gênero e orientações sexuais/afetivas, e não apenas pessoas LGBT" (MARANHÃO, 2015, p. 8).

${ }^{8}$ Faz-se referência ao empenho desses grupos para garantirem o acesso, permanência e cultuar a religiosidade cristã, uma vez que foram historicamente e socialmente reprimidos nesses espaços. Ver ainda o trabalho de: Carlos Lacerda Coelho Júnior (2014).

${ }^{9}$ Desvio é compreendido aqui a partir da noção de Howard Becker (2008): “Desvio não é uma qualidade que reside no próprio comportamento, mas na interação entre a pessoa que comete um ato e aquelas que reagem a ele" (BECKER, 2008, p. 27).

${ }^{10}$ De acordo com Coelho Júnior (2012) essa teologia inclusiva ou, como o autor chama "teologia queer", tem as pretensões de romper com os paradigmas cristãos heterossexistas normativos que impõe normas e padrões de condutas, que sufocam principalmente a pessoa LGBT. Esta teologia visa reconfigurar elementos heteronormativos dentro da estrutura religiosa do cristianismo, afirmando ser possível sim essa mudança por meio de experiências pessoais de pessoas não heterossexuais.
} 
Religare, ISSN: 19826605, v.16, n.2, dezembro de 2019, p.461-493.

desconstrução de um paradigma cristão secular em relação aos homossexuais e suas experiências, e vivências com o sagrado cristão.

Nesta acepção, minhas investigações concentraram-se em um grupo religioso vinculado a uma destas denominações religiosas inclusivas - mais conhecidas como Comunidade Cristã Nova Esperança Internacional (CCNEI) - especificamente em uma célula religiosa ${ }^{11}$ que faz parte da CCNEI na Cidade de Pelotas, no Rio Grande do Sul. Trabalho de pesquisa realizado durante minha dissertação de mestrado. Entretanto, deixo claro, que as reflexões feitas nesse artigo se restringem exclusivamente sobre minhas reflexões acerca da metodologia aplicada na pesquisa. A pesquisa de cunho etnográfica realizada com grupo em Pelotas teve seu início em 21 de maio de 2017 e sua finalização no dia 11 de novembro de 2018 na qual acompanhei e observei sistematicamente os cultos e eventos promovidos pelo grupo religioso. Trabalho etnográfico este que busquei aliar outras técnicas de pesquisa, como observação participante e entrevistas.

O grupo religioso inclusivo em Pelotas atua na cidade desde $2015^{12}$ e faz parte de um empreendimento missionário da Igreja Comunidade Cristã Nova Esperança Internacional (CCNEI) com sede mundial no Estado de São Paulo, fundada em 2004, que visa expansão e proliferação da proposta de uma teologia inclusiva pelos Estados brasileiros. A pesquisa passou por duas fases: a primeira, exploratória, cujo principal objetivo foi conhecer os membros, o local de atuação do grupo religioso e as dinâmicas sociais que os frequentadores estabeleciam no espaço de culto religioso; a segunda

\footnotetext{
${ }^{11}$ Ainda na esteira do pensamento de Durkheim uma célula religiosa seria como uma extensão da igreja. No sentido durkheimiano: "Mesmo os cultos ditos privados, como o culto doméstico ou o culto corporativo, satisfazem essa condição, pois são sempre celebrados por uma coletividade - a família ou a corporação, não são mais que capelas de uma igreja mais vasta, a qual, por causa dessa extensão mesma, merece ainda mais ser chamada por esse nome" (DURKHEIM 2003, p. 29). Desse modo, o grupo religioso em Pelotas funciona como uma extensão da CCNEI enquanto uma instituição religiosa mais ampla e burocratizada (BOURDIEU, 2007).

${ }^{12}$ Em 2015 o Diário Popular, um jornal da cidade de Pelotas, noticiava os primeiros passos da idealização do projeto da igreja na cidade. Ver: https://www.diariopopular.com.br/geral/pastor-cria-igreja-voltadaao-publico-gay-em-pelotas-104860/. Acesso em 29 de agosto de 2018.
} 
Religare, ISSN: 19826605, v.16, n.2, dezembro de 2019, p.461-493.

etapa concentrou-se em captar os principais eventos ritualísticos, as trajetórias religiosas, interações dos frequentadores e a realização de entrevistas.

Dessa maneira, o método etnográfico, a observação participante e as entrevistas fizeram-me captar as particularidades do grupo pesquisado e as surpresas que o campo constantemente me revelava. A etnografia proporcionou-me de forma muito particular o contato com o universo das pessoas pesquisadas, em uma relação dialogal que possibilitou confrontar as minhas teorias com as teorias dos pesquisados, além de revelar as particularidades e idiossincrasias do grupo e pessoas pesquisadas. O olhar, ouvir e escrever, nos termos de Whyte (2005), Oliveira (1996) e Beaud e Weber (2014) possibilitaram-me, por vezes, ouvir informações precisas. Muito mais que fazer meras especulações sobre o grupo pesquisado, importava-me mostrar esses interlocutores e seu universo social real, tal como é, prestar uma atenção clínica em suas ações e relações (WEBER \& BEAUD, 2014). A observação participante fez-me ver de perto o locus de atuação do grupo; participar dos rituais realizados; para que eu pudesse ser aceito pelo grupo; ver de perto as relações que os membros estabeleciam entre si; a viver experiências e emoções.

Nesse contexto, meu principal objetivo com esse artigo é discutir sobre a escolha da temática de pesquisa e o método de investigação aplicado, que contou com a realização de uma etnografia, observação participante e entrevistas semiestruturadas. Busco ainda revelar ao leitor minhas percepções e experiências vividas em campo, bem como, as formas de como fui afetado durante o tempo que estive imerso no grupo. Esses compartilhamentos de vivências e interações com as pessoas do grupo pesquisado deram-se a partir de relações de trocas mútuas e de negociações sociais entre mim e as pessoas do grupo, onde eu respeitava todos os limites que me eram colocados. Isso fez com que em certa medida estabelecêssemos uma relação de confiança que permitiram-me fazer parte de muitas de suas experiências cotidianas. Trazer essas discussões permitirão o leitor perceber as eventuais sensações e impressões pelas que passam o pesquisador no desenvolvimento de uma pesquisa de cunho 
Religare, ISSN: 19826605, v.16, n.2, dezembro de 2019, p.461-493.

etnográfica e a importância desse recurso metodológico para a compreensão da realidade social, de grupos e pessoas.

\section{Métodos e técnicas de pesquisa adotada: algumas reflexões}

Na medida em que pretendo descrever grupos humanos, o método etnográfico oportuniza conhecer as particularidades das pessoas pesquisadas e seus ambientes, além de viabilizar uma mistura equilibrada de observação, entrevista e estudo em arquivo (ANGROSINO, 2009), além de ter como ponto de partida os fenômenos e vivências do grupo observado (BEAUD \& WEBER, 2014). As pretensões pela escolha do método etnográfico deram-se a partir de uma pesquisa exploratória realizada na CCNEI de Macapá, no Norte do Brasil em 2016; por minha vontade pessoal de realizar um trabalho etnográfico e em seguida pela pesquisa exploratória de aproximadamente um mês no espaço do grupo religioso da CCNEI na cidade de Pelotas.

Ao adotar o método etnográfico no domínio da sociologia, recebi algumas críticas. Recordo-me diversas vezes que fui questionado por estar fazendo etnografia e observação participante na Sociologia, assim como fui alertado de não confundir a "etnografia na antropologia" com a "etnografia na sociologia", como se a etnografia fosse de domínio único e exclusivo da Antropologia. Por vezes não compreendia tais questionamentos. Ouvi ainda, de colegas e professores: “teu trabalho é muito antropológico para a sociologia", pelo fato, justamente de está utilizando a etnografia enquanto método de investigação no domínio da sociologia. Tais questionamentos colocados trazem à tona o clássico debate de um academicismo que insiste em separar e colocar cada ciência em sentido compartimentalizado e mais ainda de um antigo debate acerca da institucionalização da Sociologia e a sua recusa pela etnografia (WEBER \& BEAUD, 2014). Concordando com Liedke (2011) hoje essa divisão disciplinar nas ciências sociais vem sendo superada, principalmente no que tange a utilização de autores, temas e metodologia de pesquisa adotada. Nesse sentido, assim como Florence Weber e Stéphane Beaud (2014) saio em defesa de uma etnografia sociológica. 
Religare, ISSN: 19826605, v.16, n.2, dezembro de 2019, p.461-493.

Creio sim que existam algumas precauções que se devam tomar com a utilização desde método nas ciências humanas e sociais, principalmente porque uma etnografia não se faz em um ou dois meses e tem toda sua tradição na Antropologia, porém, todo bom cientista social sabe da utilização da observação participante e etnografia utilizada por alguns conhecidos e renomados sociólogos. Sejam nos trabalhos de perspectivas etnográficas de Bourdieu (2011) Durkheim (1996) e Weber (2003), como também nos trabalhos desenvolvidos pelos estudiosos da Escola de Chicago e seus estudos em Sociologia e Antropologia Urbana (MAGNANI, 1996). Neste segmento, Florence Weber e Stéphane Beaud (2014) admitem a possibilidade do método etnográfico para além das fronteiras da Antropologia. Para Weber e Beaud (2014) a partir da década de 1980 com as crises dos modelos teóricos do marxismo e do estrutural-funcionalismo e também das críticas dos etnometodólogos às pesquisas estatísticas possibilitaram à Sociologia as descobertas da observação e das pesquisas de campo. Os autores ilustram a obra de Pierre Bourdieu, "A distinção", como um exemplo de uma etnografia sociológica. Nesse contexto, os escritos de Weber e Beaud (2014) servem como um guia para os que optam, dentro da Sociologia, pelo método etnográfico e mais que isso combate a divisão entre Antropologia e Sociologia no que diz respeito ao uso da etnografia e propõem então uma etnografia sociológica (WEBER \& BEAUD, 2014, grifos dos autores).

Florence Weber e Stéphane Beaud (2014) apresentam três condições básicas de uma pesquisa etnográfica. São elas: o interconhecimento, reflexividade ou autoanálise e a longa duração - procedimentos que busquei seguir arisca no desenvolvimento dessa pesquisa.

O interconhecimento está centrado na ideia onde todos do grupo se conhecem e estão em relação direta uns com os outros (WEBER E BEAUD, 2014). Dessa maneira, a escolha do método etnográfico possibilitou-me perceber esse interconhecimento que existia no grupo pesquisado, principalmente fez-me analisar as redes de relações entre as pessoas. Um bom exemplo disso está expresso no seguinte momento observado em campo: muitas das pessoas que frequentavam ou frequentaram o grupo religioso da 
Religare, ISSN: 19826605, v.16, n.2, dezembro de 2019, p.461-493.

CCNEI em Pelotas haviam conhecido o Presbítero Sandro ${ }^{13}$ - principal responsável pelo grupo da CCNEI em Pelotas - em alguma ocasião de suas vidas, sejam elas quando ele atuou como interprete de libras, da Igreja Pentecostal Brasa, quando ele trabalhou em organizações de eventos, da Universidade ou até mesmo de boates destinadas ao público LGBT as quais Sandro frequentara no passado. Já outros frequentadores chegavam até a CCNEI através de membros mais antigos, ou seja, pelas redes sociais e emotivas que compartilhavam.

No tocante a reflexividade, isto se refere ao trabalho do pesquisador em campo, do qual ele, sem cessar, deve analisar o que se passa, relacionando-o ao que faz. Refere-se ainda a vigilância que o pesquisador deve ter em ser capaz de examinar as condições sociais, materiais, culturais, intelectuais e políticas das quais os dados etnográficos são produzidos (WEBER \& BEAUD, 2014). Relaciona-se ainda com aquilo que o faz ver e ouvir, é a "surpresa", se estou surpreso é porque esperava por outra coisa (WEBER \& BEAUD, 2014 p. 193).

Diversas vezes as surpresas no campo de pesquisa foram corriqueiras, algo que eu não podia prever acontecia de forma inesperada. Certa vez, fiquei duas semanas sem ir ao culto, ao voltar eu estava diante de fatos dos quais eu não esperava. Mais que em seguida, a partir da análise das anotações no diário de campo e de uma reflexão sobre o grupo eu chegava à conclusão de que "as surpresas" possuíam sentido e significados diversos, principalmente tratando-se do grupo pesquisado. (WEBER E BEAUD, 2014).

Um exemplo bem ilustrativo dessas supressas foi o noivado e o casamento do Sandro. Em um determinado tempo em campo nem sequer ouvia-se falar sobre ele ter um relacionamento. Duas semanas depois ele era noivo - havia conhecido um pastor de uma igreja inclusiva americana, a Metropolitan Community Churches, por um site de relacionamento voltado para "Gays Cristãos" (Gays Cristian); namoraram via internet durante algum tempo, depois noivaram e em seguida casaram-se na cidade

\footnotetext{
${ }^{13}$ Nome fictício para proteger o anonimato do interlocutor. Bem como, todos os outros que irão aparecer no decorrer desse artigo.
} 
Religare, ISSN: 19826605, v.16, n.2, dezembro de 2019, p.461-493.

de Pelotas, após a vinda do noivo para o Brasil. O noivado e o casamento do presbítero foram fatos que despertavam elogios de muitos frequentadores, além de corroborar com um discurso difundido pela instituição CCNEI sobre o casamento e a relação monogâmica estável entre pessoas do mesmo sexo.

Outra surpresa que destaco foi com a presença do Demétrio em um dos cultos. O Demétrio era um jovem que morou durante algum tempo em um mesmo pensionato que eu em Pelotas. Ele era um jovem com problemas mentais, diziam que ele era esquizofrênico, nunca soube ao certo. Certa vez, em um surto, Demétrio agrediu com um pedaço de madeira alguns dos moradores do pensionato e quebrou boa parte dos utensílios que ficavam na sala e na cozinha. Devido ao comportamento dele, o dono do pensionato chamou a polícia e em seguida pediu para que ele procurasse outro lugar para morar. Surpreendi-me com o Demétrio no culto, com a Bíblia na mão, muito compenetrado. Era primeira vez que ele me cumprimentava e se mostrava mais sociável do que habitualmente era no tempo que moramos juntos. Por alguns momentos ele nem parecia ser a mesma pessoa que eu havia conhecido no pensionato, foi sociável, quis saber o que eu fazia na célula, como eu tinha conhecido o grupo e me relatava que já conhecia o Sandro há algum tempo e que estava na célula porque era "um cristão e queria estar mais perto de Deus".

Em nenhum momento o Demétrio comentou sobre o ocorrido no pensionato, apenas perguntava sobre alguns moradores e seus pertences que haviam ficado lá. Eu, muito sereno, respondia que eu já não morava no pensionato há quase mais de um ano. Observei neste dia que a participação dele nos cultos fazia parte de um "resgate" ou do que o Sandro dizia em alguns cultos "Deus traz das trevas para a luz" ${ }^{14}$. Esse resgate era acionado como estratégia de conversão e mecanismo de pertencimento ao grupo, atitudes similares podem ser encontradas em muitas igrejas evangélicas. $\mathrm{O}$ Demétrio, com todos os seus problemas pessoais, estava afastado de religião e seu regresso a um espaço sagrado era responsável por ele tentar controlar seus demônios,

\footnotetext{
${ }^{14}$ Diário de campo, 18 de março de 2018.
} 
Religare, ISSN: 19826605, v.16, n.2, dezembro de 2019, p.461-493.

seus pecados e entender a lidar com eles, era dessa forma que ele compreendia a sua volta a um espaço religioso. De fato, ele parecia mais comunicativo no grupo, participou de alguns eventos e até se aproximou mais de mim para falar de suas viagens e de suas projeções para o futuro. A sociabilidade no grupo parecia despertar o Demétrio para as relações sociais e o tiravam de um certo isolamento social que lhe eram colocados por conta das limitações que ele possuía.

No que concerne à longa duração, Weber e Beaud (2014) chamam atenção para importância do período de realização da pesquisa etnográfica e que ela não pode ser realizada em três ou quatro dias. De acordo com Weber e Beaud (2014) o tempo passado no local propícia, verdadeiros "encontros", de verdadeiros "intercâmbios diferenciados" (WEBER \& BEAUD, 2014, p. 195). Além disso, apesar do tempo que estive em campo, como sugerem os autores, não abri mão das observações, entrevistas e coletas de documentos, pelo contrário, essas combinações de métodos e técnicas de pesquisa foram ferramentas de análises importantíssimas.

No tocante a escolha pela observação participante deu-se principalmente pelo contato com os estudos de William Foote Whyte (2005) que explicita com maestria os fundamentos de uma observação participante nos estudos de grupos em sociedades complexas. Para Whyte (2005) fazer uma observação participante consiste, antes de tudo, em um longo processo, que envolve negociações para entrada no campo de pesquisa, fato já explicitado; uma fase de pesquisa exploratória (que também foi realizada) que é de profunda relevância para o desenvolvimento posterior da pesquisa no local; o tempo, que se configura como sendo essencial para os estudos que tratam de comportamentos e ações de grupos. Na visão de Whyte para captar as idiossincrasias das pessoas e de grupos é necessário observá-los por um longo período e não em um único momento.

Conforme Whyte (2005) a observação participante pressupõe a interação entre pesquisador/pesquisado. Todas as informações captadas, as indagações suscitadas resultarão do comportamento e das relações que se estabelecem com as pessoas do grupo pesquisado. Além do que, a presença do pesquisador tem que ser justificada e 
Religare, ISSN: 19826605, v.16, n.2, dezembro de 2019, p.461-493.

sua transformação em "nativo" não se verificará, ainda que o pesquisador esteja inserido, presentes nas reuniões do grupo, ele será visto sempre com "curiosidade" quando não com desconfiança (WHYTE, 2005, p. 301). O pesquisador deve se reconhecer como uma pessoa de fora e seu papel no grupo deve sempre ser reafirmado. Parafraseando Whyte (2005) “as pessoas não esperam que você seja como elas, elas te aceitam por que você é diferente". Sendo assim, há uma impossibilidade de imersão total ao grupo.

Outra questão levantada por Whyte (2005) é que uma observação participante só é possível com o contato com uma informante chave que possibilita a entrada ao campo, o que o autor chama de "DOC". É o DOC que irá fornecer informações importantes e se tornará aquela pessoa que irá tirar eventuais dúvidas do pesquisador. Ainda de acordo com Whyte (2005), o próprio pesquisador fica em dúvida sobre o que ele representa para o grupo, muito de seus passos durante a pesquisa são conhecidos e manipulados pelos interlocutores. O pesquisador estar constantemente sendo observado pelas pessoas do grupo. A observação participante exige ainda a utilização de todos os sentidos, saber ver, ouvir e esperar o momento certo de perguntar. Além do mais, fazer observação participante para Whyte (2005) é um sistemático trabalho de campo, que deve envolver presença no campo, utilização e anotações em um diário. Envolve ainda erros e acertos, e saber aprender com eles, pois, tudo isso faz parte dos trajetos da pesquisa.

Seguindo as perspectivas de Whyte (2005), meu primeiro informante chave do grupo, o "DOC", foi o Sandro. Ele sempre me forneceu informações necessárias e importantes sobre a denominação CCNEI e sobre os frequentadores, além de sempre tirar eventuais dúvidas que surgiam no decorrer da pesquisa com relação ao grupo.

Esclareço ainda que nunca estive ausente das observações e olhares curiosos e também de discernir que embora eu fosse concebido como "amigo" por alguns dos interlocutores, outros me olhavam com desconfiança e me viam como um "estranho". Esse "estranhamento" pode ser ilustrado com o caso de uma mulher lésbica que frequentou algumas reuniões do grupo, ela sentia-se extremamente desconfortável 
Religare, ISSN: 19826605, v.16, n.2, dezembro de 2019, p.461-493.

com a minha presença como pesquisador e sempre me alertava para o cuidado que eu devia ter em não citar seu nome fora do ambiente do grupo ou ainda de tirar fotos dela. Sobre erros e acertos, como sugere Whyte (2005), eu exponho o uso de câmera fotográfica em um dos eventos do grupo. A referida mulher pediu ao Sandro para falar comigo para que eu em hipótese alguma lhe fotografasse; segundo ela, não podia ter sua imagem na internet associada a um grupo religioso gay devido sua família ser tradicional e ela ainda não ser "assumida", fato este que fez com que em outros eventos eu decidisse abolir o uso de equipamentos fotográficos (WEBER \& BEAUD, 2014).

Como técnica de pesquisa utilizei a entrevista semiestruturada, de acordo com o autor Triviños (1987, p. 146), a mesma tem como característica, questionamentos básicos que são apoiados em teorias e hipóteses que se relacionam ao tema da pesquisa. $\mathrm{O}$ autor afirma que a entrevista semiestruturada "[...] favorece não só a descrição dos fenômenos sociais, mas também sua explicação e a compreensão de sua totalidade $[\ldots]^{\prime \prime}$, além de manter a presença consciente e atuante do pesquisador no processo de coleta de informações (TRIVIÑOS, 1987, p. 152). Já para Manzini (19901991, p. 154), a entrevista semiestruturada estar focalizada em um assunto sobre o qual confeccionamos um roteiro com perguntas principais, complementadas por outras questões inerentes às circunstâncias momentâneas à entrevista. Para o autor, esse tipo de entrevista pode fazer emergir informações de forma mais livre e as respostas não estão condicionadas a uma padronização de alternativas.

Assim, através de um roteiro de entrevistas semiestruturadas, entrevistei o Presbítero Sando responsável pela CCNEI em Pelotas, as pessoas que frequentavam com mais assiduidade e aqueles que deixaram de frequentar o grupo. As perguntas estavam destinadas a identificar o perfil dos frequentadores do grupo, as trajetórias e experiências religiosas, o sentido que a teologia inclusiva assumia em suas vidas, sobre o sentimento de pertencimento, como conheceram o grupo em pelotas e sobre qual o sentido que os rituais como o batismo no Espírito Santo, a Santa Ceia, óleo ungido, oração em línguas, o louvor e o culto da fogueira, realizados no grupo religioso eram importantes para que eles voltassem a manter relações com o sagrado evangélico. 
Religare, ISSN: 19826605, v.16, n.2, dezembro de 2019, p.461-493.

As entrevistas foram realizadas com o Presbítero Sandro e mais sete homossexuais que frequentavam o grupo. As entrevistas foram negociadas e agendadas com antecedência por conta dos afazeres dos interlocutores. Alguns optaram por realizar a entrevista em locais públicos, outros em sua residência e, outros ainda, no caso do Cristiano e do Lucas, optaram em vir até a minha a casa, porque no dia da entrevista estariam nas proximidades (todos os nomes citados são fictícios).

As entrevistas duraram cerca de quarenta minutos. As entrevistas mais curtas duraram vinte minutos por conta da falta de tempo, como no caso do Israel que estava no seu trabalho e tinha uma agenda cheia por conta, também, da faculdade; com o Cristiano, que tem problemas na voz (gagueira) e era muito tímido e com o Demétrio que se mostrou ressabiado, dizendo que estava com pouco tempo e que não tinha muito o que falar. As entrevistas deram-se sempre em tom de muita descontração e com a preocupação de deixá-los sempre muito à vontade.

Sendo assim, o método etnográfico associado à observação participante e as entrevistas oportunizaram-me conhecer, participar e desvendar aspectos muitos particulares do grupo. Abaixo o leitor poder visualizar os quadros de entrevista e todos os eventos que estive presente durante a realização da pesquisa.

TABELA 1: CULTOS E EVENTOS IMPORTANTES 
Religare, ISSN: 19826605, v.16, n.2, dezembro de 2019, p.461-493.

\begin{tabular}{|c|c|c|}
\hline DIA DO CULTO & FREQUENTADORES & $\begin{array}{l}\text { ACONTECIMENTOS DO } \\
\text { CULTO }\end{array}$ \\
\hline 21 DE MAIO DE 2017 & $\begin{array}{l}\text { PRESBÍTERO SANDRO } \\
\text { CRISTIANO } \\
\text { JOCA } \\
\text { DAVID } \\
\text { MARCELO }\end{array}$ & $\begin{array}{l}\text { EVENTO: “CAFÉ DA TARDE” } \\
\text { ORAÇÃO INICIAL } \\
\text { LOUVOR } \\
\text { LEITURAS DE PASSAGENS } \\
\text { BÍBLICAS } \\
\text { PEDIDO DE ORAÇÃO } \\
\text { LOUVOR } \\
\text { MINISTRAÇÃO DA PALAVRA } \\
\text { PEDIDO DE ORAÇÃO }\end{array}$ \\
\hline 25 D E JUNHO DE 2017 & $\begin{array}{l}\text { MARCELO } \\
\text { CLEITON }\end{array}$ & $\begin{array}{l}\text { EVENTO: CULTO } \\
\text { MINISTRADO PELO } \\
\text { MARCELO } \\
\text { ORAÇÁO INICIAL } \\
\text { LOUVOR } \\
\text { LEITURAS DE PASSAGENS } \\
\text { BÍBLICAS } \\
\text { PEDIDO DE ORAÇÃO } \\
\text { LOUVOR } \\
\text { MINISTRAÇÃO DA PALAVRA } \\
\text { PEDIDO DE ORAÇÃO }\end{array}$ \\
\hline 21 DE JANEIRO 2018 & $\begin{array}{l}\text { PRESBÍTERO SANDRO } \\
\text { GUSTAVO } \\
\text { MARCELO } \\
\text { GABRIEL } \\
\text { CLEITON } \\
\text { ISRAEL }\end{array}$ & $\begin{array}{l}\text { CULTO NORMAL } \\
\text { ORAÇÃO INICIAL } \\
\text { LOUVOR } \\
\text { LEITURAS DE PASSAGENS } \\
\text { BÍBLICAS } \\
\text { PEDIDOS DE ORAÇÃO }\end{array}$ \\
\hline 04 DE FEVEREIRO DE 2018 & $\begin{array}{l}\text { PRESBÍTERO SANDRO } \\
\text { GUSTAVO } \\
\text { LUCAS } \\
\text { MARCELO } \\
\text { GABRIEL }\end{array}$ & $\begin{array}{l}\text { EVENTO CAFÉ DA TARDE } \\
\text { ORAÇÃO INICIAL } \\
\text { LOUVOR (PELA PRIMEIRA VEZ } \\
\text { CANTADO POR UM DOS } \\
\text { FREQUENTADORES, O LUCAS) } \\
\text { ORAÇÕES EM LÍNGUAS } \\
\text { ESTRANHAS } \\
\text { LEITURAS DE PASSAGENS } \\
\text { BÍBLICAS } \\
\text { PEDIDOS DE ORAÇÃO }\end{array}$ \\
\hline 18 DE FEVEREIRO DE 2018 & ---------------------------- & $\begin{array}{l}\text { FUI PARA TER UMA } \\
\text { CONVERSA COM O } \\
\text { PRESBÍTERO SANDRO SOBRE } \\
\text { O RETIRO DE CARNAVAL QUE } \\
\text { O GRUPO PROMOVEU NO }\end{array}$ \\
\hline
\end{tabular}


Religare, ISSN: 19826605, v.16, n.2, dezembro de 2019, p.461-493.

\begin{tabular}{lll}
\hline \multirow{2}{*}{25 FEVEREIRO DE 2018} & & MUNICÍPIO DE SÃO \\
& PRESBÍTERO SANDRO & CULTONÇO, RS \\
& MARCELO & ORAÇÃO INICIAL \\
& LUCAS & LOUVOR \\
& JOCA & ORAÇÕES EM LÍNGUAS \\
& GUSTAVO & ESTRANHAS \\
& DANIEL & LEITURAS DE PASSAGENS \\
& & BÍBLICAS \\
18 DE MARÇAO DE 2018 & PEDIDOS DE ORAÇÃO \\
& MARCELO & EVENTO: CULTO REALIZADO \\
& CLEITON & NA CASA DO CLEITON \\
& GABRIEL & ORAÇÃO INICIAL \\
DEMÉTRIO & LOUVOR \\
& LEITURAS DE PASSAGENS \\
& BÍBLICAS \\
& PEDIDOS DE ORAÇÃO \\
& & \\
& & CULTO NORMAL \\
& PRESBÍTERO SANDRO & ORAÇÃO INICIAL \\
& GUSTAVO & LOUVOR \\
MARCELO & RITUAL DA SANTA CEIA \\
& DEMÉTRIO & LEITURAS DE PASSAGENS \\
& BÍBLICAS \\
& PEDIDOS DE ORAÇÃO \\
&
\end{tabular}

\begin{tabular}{lll} 
& PRESBÍTERO SANDRO & CULTO NORMAL \\
& MARCELO & ORAÇÃO INICIAL \\
& DEMÉTRIO & LOUVOR \\
& CLEITON & LEITURAS DE PASSAGENS \\
& GABRIEL & BÍBLICAS \\
& DANIEL & PEDIDOS DE ORAÇÃO \\
& PRESBÍTERO SANDRO & EVENTO: CULTO REALIZADO \\
& ANA & NA SALA DA CASA DO \\
& JULIA & SANDRO \\
& MARCELO & ORAÇÃO INICIAL \\
& CLEITON & LOUVOR \\
& GABRIEL & LEITURAS DE PASSAGENS \\
& & BÍBLICAS \\
& & PEDIDOS DE ORAÇÃO \\
& & \\
& PRESBÍTERO SANDRO & CULTO NORMAL \\
& MARCELO & ORAÇÃO INICIAL \\
& MÃE DO PRESBÍTERO & LOUVOR \\
& & MANIFESTAÇÃO DE ORAÇÃO \\
& & EM LÍNGUAS \\
& & LEITURAS DE PASSAGENS \\
& BÍBLICAS \\
\hline
\end{tabular}


Religare, ISSN: 19826605, v.16, n.2, dezembro de 2019, p.461-493.

\begin{tabular}{|c|c|c|}
\hline & & PEDIDOS DE ORAÇÃO \\
\hline 27 DE MAIO DE 2018 & $\begin{array}{l}\text { PRESBÍTERO SANDRO } \\
\text { MARCELO } \\
\text { CLEITON } \\
\text { GABRIEL } \\
\text { MÃE DO PRESBÍTERO }\end{array}$ & $\begin{array}{l}\text { CULTO NORMAL } \\
\text { ORAÇÃO INICIAL } \\
\text { LOUVOR } \\
\text { LEITURAS DE PASSAGENS } \\
\text { BÍBLICAS } \\
\text { PEDIDOS DE ORAÇÃO }\end{array}$ \\
\hline 24 DE JUNHO & $\begin{array}{l}\text { PRESBÍTERO SANDRO } \\
\text { MARCELO } \\
\text { CLEITON } \\
\text { GABRIEL } \\
\text { MÃE DO PRESBITERO } \\
\text { SANDRO } \\
\text { DAVID } \\
\text { DEMÉTRIO } \\
\text { AMIGA DO } \\
\text { PRESBÍTERO E SUAS } \\
\text { DUAS FILHAS } \\
\text { PASTOR JOÃO } \\
\text { MULHER DO PASTOR } \\
\text { JOÃO } \\
\text { MÃE DO CLEITON } \\
\text { ANA } \\
\text { JULIA }\end{array}$ & $\begin{array}{l}\text { EVENTO: } 3^{\circ} \text { ARRAIAL } \\
\text { GOSPEL DA CCNEI } \\
\text { ORAÇÃO INICIAL } \\
\text { LOUVOR } \\
\text { LEITURAS DE PASSAGENS } \\
\text { BÍBLICAS } \\
\text { PEDIDOS DE ORAÇÃO } \\
\text { RITUAL DA FOGUEIRA }\end{array}$ \\
\hline 8 DE JUNHO DE 2018 & $\begin{array}{l}\text { PRESBÍTERO SANDRO } \\
\text { GABRIEL }\end{array}$ & $\begin{array}{l}\text { EVENTO: O PASTOR } \\
\text { ENSINAVA EM LIBRAS } \\
\text { ESTUDOS BÍBLICOS PARA O } \\
\text { GABRIEL }\end{array}$ \\
\hline 22 DE JUNHO DE 2018 & $\begin{array}{l}\text { PRESBÍTERO SANDRO } \\
\text { MÃE DO PRESBÍTERO }\end{array}$ & $\begin{array}{l}\text { CULTO NORMAL } \\
\text { ORAÇÃO INICIAL } \\
\text { LOUVOR } \\
\text { RITUAL DO ÓLEO UNGIDO } \\
\text { MANIFESTAÇÃO DE ORAÇÃO } \\
\text { EM LÍNGUAS } \\
\text { LEITURAS DE PASSAGENS } \\
\text { BÍBLICAS } \\
\text { PEDIDOS DE ORAÇÃO }\end{array}$ \\
\hline
\end{tabular}

FONTE: AUTOR

Tabela 2. Quadros de entrevistas

\begin{tabular}{lll}
\hline DATA & ENTREVISTADO & LOCAL \\
\hline 08 DE NOVEMBRO DE & LUCAS & MINHA CASA \\
2018 & & \\
08 DE NOVEMBRO 2018 & CRISTIANO & MINHA CASA \\
09 DE NOVEMBRO 2018 & ISRAEL & CENTRO DE ARTES - UFPel \\
\hline
\end{tabular}


Religare, ISSN: 19826605, v.16, n.2, dezembro de 2019, p.461-493.

\begin{tabular}{lll}
\hline $\mathbf{1 0}$ DE NOVEMBRO 2018 & SANDRO & CASA DO CLEITON E \\
& & MARCELO \\
$\mathbf{1 0}$ DE NOVEMBRO 2018 & MARCELO & EM SUA RESIDÊNCIA \\
$\mathbf{1 0}$ DE NOVEMBRO 2018 & CLEITON & EM SUA RESIDÊNCIA \\
\hline $\mathbf{1 1}$ DE NOVEMBRO 2018 & DEMÉTRIO & PRAÇA CORONEL PEDRO \\
& & OSÓRIO - CENTRO DE \\
& & PELOTAS \\
$\mathbf{1 1}$ DE NOVEMBRO 2018 & DAVID & CAFETERIA - MERCADO \\
& & PÚBLICO DE PELOTAS \\
\hline
\end{tabular}

FONTE: AUTOR

\section{Contextualizando o campo de investigação: o que revelam os dados etnográficos}

\section{A Comunidade Cristã Nova Esperança Internacional (CCNEI)}

A CCNEI, com sede oficial localizada no Estado de São Paulo, foi fundada em 8 de agosto de 2004 e designada como igreja em 10 de janeiro de 2010 e tem como principal proposta a aceitação da diversidade sexual em seus espaços de culto ao sagrado. Atualmente, a sede oficial estar sob responsabilidade do pastor evangélico Justino Luiz de Oliveira ${ }^{15}$ que lidera um empreendimento de expansão do movimento religioso inclusivo no Estado de São Paulo, na região Sul e Nordeste do país. As missões missionárias da CCNEI visam em primeiro plano a criação de pequenas células religiosas com o propósito de atrair adeptos, de modo que possam institucionalizar-se como igrejas nessas regiões, como é o caso do grupo religioso em Pelotas, RS. Na página inicial do site da CCNEI, sede internacional, na aba "quem somos" o leitor fica sabendo sobre a data de fundação da denominação e suas principais características enquanto uma igreja cristã inclusiva ${ }^{16}$. Os discursos vinculados por esta denominação estão diretamente ligados às práticas religiosas cristãs e identidades LGBTs, interpretando-as não mais como pecado, mas sim como uma expressão da sexualidade humana, que passa ser tão santa e bem vista, quanto à heterossexualidade.

\footnotetext{
15 Ver: http://www.ccnei.org/. Acesso em 10 de outubro de 2017.

16 Ver: http://www.ccnei.org/. Acesso em 10 de outubro de 2017.
} 
Religare, ISSN: 19826605, v.16, n.2, dezembro de 2019, p.461-493.

A CCNEI estar inserida no universo simbólico e cultural evangélico pentecostal, porém, com algumas modificações, principalmente no que diz respeito às leituras bíblicas que condenam e reprovam a homossexualidade (NATIVIDADE, 2010). Dessa maneira, a denominação inclusiva CCNEI leva em consideração alguns aspectos da cosmologia pentecostal, que se caracteriza historicamente pelo batismo no Espírito Santo - que se configura enquanto eixo central desta religiosidade ${ }^{17}$; orações em línguas estranhas e a volta iminente de Cristo. Assim, a CCNEI possui esses elementos que lhe configuram enquanto uma igreja pentecostal, isto pode ser acompanhado na divulgação do site da instituição e no folheto informativo de vinte e uma páginas ${ }^{18}$ oferecido, no curso de integração de novos membros que traz todas as informações sobre as características da CCNEI.

A hierarquia na igreja é semelhante à de uma igreja evangélica pentecostal ou neopentecostal, na qual se tem: a figura do pastor como líder ou presidente, o presbítero, diácono, demais cargos administrativos e os membros, em particular inspirada em estruturas organizacionais da Assembleia de Deus (RODRIGUES, 2009; NATIVIDADE, 2008). Isso se dá pelo fato de seus líderes serem egressos de denominações evangélicas pentecostais e neopentecostais diversas. No que diz respeito a esta assertiva o Pr. Fundador da $\mathrm{CCNEI}^{19}$ é egresso de uma denominação pentecostal chamada Igreja Evangélica Pentecostal da Transfiguração, igreja no qual passou pelos ritos de iniciação e passagem (GENNEP, 2011). No pentecostalismo, o pastor Justino foi batizado por imersão, atuou em ministérios e passou pelos ritos de consagração (obreiro, diácono, evangelista) até se tornar pastor em 1990. Após romper

\footnotetext{
${ }^{17}$ De acordo com Mariano (1999), o pentecostalismo ${ }^{17}$ teve como centro irradiador da mensagem do seu evangelho para o mundo, a Rua Azuza, em Los Angeles, no Estado da Califórnia (EUA), organizada pelo líder Seymour, de onde se espalhou rapidamente. Para Seymour, havia três estágios na "vida espiritual" do pentecostal: a conversão, também definida como regeneração; santificação, que era necessária para "purificar o coração" e o batismo do Espírito Santo ${ }^{17}$, tendo como sinal o dom de línguas (Glossolalia ou Xenoglossia). Passos (2005) aponta que esse impulso missionário era fortemente revigorado pela expectativa da iminente volta de Cristo ao mundo e alimentado pelas rápidas transformações por qual a sociedade passava em meados do século XX.

${ }^{18} \mathrm{O}$ Sandro da CCNEI Pelotas me deu um exemplar deste folheto para que eu ficasse sabendo de todas as informações acerca da denominação.

${ }^{19}$ Em: http://ccnei.org/pastor-justino/. Acesso em 22 de setembro de 2018.
} 
Religare, ISSN: 19826605, v.16, n.2, dezembro de 2019, p.461-493.

com um pentecostalismo mais conservador, participou primeiro da Igreja Inclusiva Acalanto $^{20}$ e em 2004, após um "racha" ${ }^{21}$ com a igreja Acalanto ajudou na fundação da $\mathrm{CCNEI}^{22}$ no mesmo ano.

Nessa circunstância, a partir das características já mencionadas, considero a CCNEI, assim como Natividade (2008) e Maranhão (2015) como uma denominação pentecostal que é herdeira do princípio do "sacerdócio universal23". Uma denominação dissidente que surge a partir de características próprias desse movimento como os "cismas" e "rachas" que dão origem a novas iniciativas religiosas, diferentes modalidades de produzir e reproduzir lideranças, produzindo recursos materiais e simbólicos característicos do pentecostalismo (BOURDIEU, 2007, FERNANDES, 1998, p. 8).

\section{Caracteristicas da CCNEI Pelotas: breves reflexões}

O lugar de culto é uma casa localizada na Rua Barão de Itamaracá, no Bairro $\mathrm{Areal}^{24}$, na cidade de Pelotas, no Rio Grande do Sul ${ }^{25}$. A cara era gradeada, com um espaço grande na frente, de cores laranja e amarela, afastada do centro da cidade. Ao chegar, fui bem recepcionado pelo Sandro e sua mãe, uma senhora aposentada, negra que tinha por volta dos sessenta e seis anos de idade. Em seguida, fui direcionado até o lugar onde se realizavam os encontros do grupo religioso que ficava nos fundos da casa. Para chegar até este local primeiramente era preciso prender a cadela que guardava um pequeno portão, depois passar por um corredor estreito e um pátio maior. O local de culto era nos fundos da casa, em cor branca desbotada em um espaço

\footnotetext{
${ }^{20}$ Para saber mais sobre a igreja acalanto ver os trabalhos de Natividade (2008); Rodrigues (2009); Weiss de Jesus (2012) e Coelho Júnior (2014).

${ }^{21}$ Sobre esse "racha" ver os trabalhos de Rodrigues (2009) e Coelho Júnior (2014).

22 Para Rodrigues (2009) a CCNE surge a partir de "uma ala dissidente da Igreja Acalanto" mais "pentecostal" (ROGRIGUES, 2009, p. 26).

23 "O sacerdócio universal" refere-se a crença cristã das passagens existentes no novo testamento. A crença nas palavras biblicas que guia as condutas morais dos fiéis, na salvaçao pelos arrependimentos do pecado e práticas da fé e tendo Jesus cristo como o unico salvador.

${ }^{24} \mathrm{O}$ Areal é o segundo Bairro mais populoso da cidade de Pelotas segundo dados do IBGE 2010.

${ }^{25}$ A cidade de Pelotas tem uma população estimada em 2018 de 341.648 habitantes de acordo com dados oficiais do IBGE. Ver: https://cidades.ibge.gov.br/brasil/rs/pelotas/panorama.
} 
Religare, ISSN: 19826605, v.16, n.2, dezembro de 2019, p.461-493.

de três pequenos cômodos. Na entrada uma pequena sala, sob o sofá tinha alguns livros e papeis. Adentrando mais o pequeno cômodo tinha um banheiro com apenas o vaso sanitário e pia; depois um outro espaço similar a um quarto grande de casal onde havia algumas cadeiras brancas de plástico organizadas em círculos, na frente das cadeiras uma mesa, nelas estavam algumas bíblias e em uma outra mesinha um computador que tocava alguns louvores gospel na plataforma de vídeos online YouTube e uns panfletos de divulgação coloridos escritos "Comunidade Cristã Nova Esperança Internacional Pelotas; Uma IGREJA que acolhe a Diversidade Humana"26.

Atuando desde 2015, este, é, portanto, o lugar de culto religioso da CCNEI de Pelotas. Durante a pesquisa, constatei que o grupo em Pelotas contava com um número reduzido de membros, variando de 6 a 8 pessoas nos cultos. Segundo o Presbitério Sandro e dados de observação, existem pessoas que com certa regularidade frequentava os encontros, aquelas que compareciam esporadicamente e aqueles que pararam de frequentar. $\mathrm{O}$ afastamento dava-se por motivos diversos: devido ao grupo ser pequeno e não institucionalizado enquanto uma igreja; pelas questões de horários de realização dos encontros; conflitos internos ao grupo; por pessoas que optavam em congregar em outras igrejas evangélicas ou denominações inclusivas e pela opção de algumas pessoas em se afastar de espaços religiosos. A presença dos frequentadores era, de fato, muito fluida, ou seja, não existia, por parte dos frequentadores, o sentimento de pertencimento ao segmento religioso. Os frequentadores na sua maioria eram homossexuais masculinos e assumidos publicamente. Os que não eram assumidos, assumiram-se homossexuais para seus familiares e amigos no decorrer da pesquisa. Alguns deles viam no grupo um recomeço, um campo de possibilidades ${ }^{27}$ para voltar a atuarem em cargos que tinham abandonado em algumas igrejas evangélicas que fizeram parte, como: ministério de dança, teatro e outros.

Todos os homossexuais (Gays e Lésbicas) que passaram pelo grupo religioso

\footnotetext{
${ }^{26}$ Diário de campo, 21 de maio de 2017.

27 Cf.: Velho, 2003.
} 
Religare, ISSN: 19826605, v.16, n.2, dezembro de 2019, p.461-493.

possuíam idades entre 18 e 40 anos. O perfil era de estudantes universitários, vendedores, trabalhadores informais e organizadores de eventos. Eram homens negros, pardos e brancos, das classes popular e média da cidade de Pelotas.

Os homossexuais que frequentaram o grupo afirmaram que sofreram privações e viveram alguns dilemas e conflitos em relação à homossexualidade e suas vivências religiosas nos espaços de algumas igrejas evangélicas - pentecostais e neopentecostais. Muitos desses indivíduos viam na CCNEI uma oportunidade de se reintegrarem novamente ao sagrado cristão.

Dessa forma, concordo com Natividade (2010) que o movimento de igrejas inclusivas tem como principais protagonistas pessoas que são egressas de denominações evangélicas ou católicas, rechaçados e estigmatizados em suas igrejas de origem. A CCNEI de Pelotas marcava, então, uma espécie de communitas $^{28}$ nos termos de Turner (1974;2005) (lugar de reintegração) após um período de liminaridade ${ }^{29}$ (fora de um determinada estrutura social) na vida daqueles indivíduos que a procuravam geralmente, por terem tido suas trajetórias marcadas por conflitos, no que diz respeito a opção sexual e sua opção religiosa.

Constatei durante a pesquisa que os frequentadores, em sua maioria, comungavam com as mesmas ideias doutrinárias presentes em muitas igrejas pentecostais evangélicas, como o ideal de relacionamento monogâmico, pautados estritamente na fidelidade e sexo a dois, a ideia do casamento e da construção de uma base familiar solida que cumprem os "desígnios de Deus" e o reconhecimento do pecado e afastamento dele. Nessa acepção, os trabalhos como: o de Coelho Júnior (2014) e Oliveira (2015) demonstraram que algumas igrejas inclusivas, principalmente de posturas evangélicas, são responsáveis por continuar mantendo uma lógica de extensão da heteronormatividade cristã em suas doutrinas e que essas igrejas atuam como importantes espaços de sociabilidade para troca de vivências e experiências de pessoas homossexuais cristãs evangélicas.

\footnotetext{
${ }^{28}$ Cf.: Turner $(1974 ; 2005)$.

${ }^{29}$ Cf.: Turner $(1974 ; 2005)$.
} 
Religare, ISSN: 19826605, v.16, n.2, dezembro de 2019, p.461-493.

Todos os frequentadores possuíam trajetórias no meio evangélico, principalmente evangélico pentecostal, porém, já haviam transitado em outras denominações religiosas com posturas doutrinárias contrárias as deste segmento - como as de vertentes afro-brasileiras, espiritismo e catolicismo, contudo, estas experiências e a oferta de bens sagrados dessas denominações não foram capazes de produzir sentido as suas vidas e práticas enquanto cristãos evangélicos (ALMEIDA \& MONTEIRO, 2001).

No momento de socialização no grupo religioso, na maioria das vezes as conversas eram acompanhadas de chimarrão, pipoca ou outras guloseimas. Enquanto o chimarrão passava de mão em mão, as risadas, as "tiradas" de brincadeiras uns com os outros rolavam, acompanhada de estrondosas gargalhadas ${ }^{30}$. Como já mencionado, a responsabilidade de conduzir a célula é do presbítero Sandro, que contava com ajuda do fiel Marcelo, que desempenhava algumas funções como a de administrar a página do grupo na rede social Facebook, organizar os eventos e cuidar de alguns aspectos mais burocráticos. Antecipo ao leitor que atualmente o Marcelo não faz mais parte da CCNEI devido alguns dilemas que teve com o Presbítero Sandro e as formas que este vinha conduzindo o grupo. Durante muito tempo, Marcelo esteve empenhado no projeto de expansão da religiosidade inclusiva no Sul, mas no final da pesquisa o via esgotado e desmotivado, assim como o próprio Sandro. No período de maior engajamento do grupo o Marcelo andava muito atarefado indo à imobiliária na tentativa de alugar um prédio para a igreja. Em alguns inesperados encontros nas ruas da cidade ele se desculpava por não ter dado a mim a atenção devida, "muita correria, de um lado para o outro" dizia ele. Porém, o Marcelo viu-se exausto quando as pessoas não estavam tão compromissadas quanto ele em "erguer" e dar "visibilidade" para o grupo em Pelotas, além do mais, o fato das pessoas não continuarem frequentando o grupo lhe deixou um tanto quanto frustrado, segundo relatos do próprio Marcelo, ele não viu muita força de vontade no Sandro e nas demais pessoas em querer se

\footnotetext{
${ }^{30}$ Diário de Campo, dia 28 de janeiro de 2018.
} 
Religare, ISSN: 19826605, v.16, n.2, dezembro de 2019, p.461-493.

constituírem enquanto uma igreja. Hoje o Marcelo e seu companheiro Cleiton fazem parte de outra igreja inclusiva - a Filhos da Luz.

Do início ao final da pesquisa foi possível visualizar que os principais meios de divulgação do grupo davam-se a partir do acionamento de redes afetivas e de contatos pessoais, de amizades e na página que o grupo hospedava no Facebook e WhatssApp na qual ocorre constante divulgação dos cultos e dos demais eventos da célula religiosa. No entanto, o acionamento dessas redes afetivas e a divulgação constante nas redes sociais não foram suficientes para atrair pessoas e aumentar os números de membros, devidos o proselitismo da CCNEI de Pelotas ser fraco e pouco atuante na cidade, além de uma dificuldade de estabelecer relações com o movimento LGBT da cidade.

\section{O ser afetado: Vivências, experiências e emoções.}

Dedico este tópico para explicitar como fui afetado durante a realização da pesquisa. O convívio com o grupo durante quase mais de um ano, fez com que eu sentisse emoções e sensações que me fizeram, por vezes, refletir sobre o papel do pesquisador, principalmente de uma figura clássica de pesquisa em que se evita ao máximo não criar vínculos com as pessoas pesquisadas, por eu ser humano e sensível, eu não conseguia ver meus interlocutores apenas como "meros objetos de investigação", eles estavam para, além disso.

Em vista disso, uma das primeiras sucessões de acontecimentos que me deixaram de alguma forma constrangido e até desnorteado diante das pessoas que frequentavam o grupo religioso foi, em primeiro lugar, as indagações acerca da minha sexualidade; alguns interlocutores, logo no início da pesquisa, relacionavam o fato de eu pesquisar "igrejas gays" com minha condição sexual. Como ouvi certa vez: "para estudar igrejas gays só pode ser gay". Eu não hesitei em revelar minha condição sexual (de ser homossexual), senti que eu precisava, antes de tudo, ser honesto com as pessoas que me recebiam. Outro fato, era o de o Presbítero Sandro, assim como alguns interlocutores, terem conhecimento sobre os autores e escritos a respeito de igrejas 
Religare, ISSN: 19826605, v.16, n.2, dezembro de 2019, p.461-493.

inclusivas e teologia inclusiva. Por vezes, em tom de deboche, acompanhado de um largo sorriso, o Sandro falava "Eu sei o que tú quer saber de nós... Se somos inclusivos mesmo... que aqui funciona como docilização dos corpos... aquela coisa toda que Foucault fala e que já escreveram... Somos uma igreja evangélica pentecostal com valores pentecostal já fica sabendo".

O Sandro vez o outra sentava e dialogava comigo sobre alguns trabalhos que ele já tinha lido, demonstrando que ele não era leigo no assunto e até desenvolvia suas próprias interpretações sobre as igrejas inclusivas e do próprio grupo, por vezes, eu sentia que o Sandro utilizava isso como forma de querer manipular a pesquisa ou conduzi-la da forma que ele imaginava (WHYTE, 2005). Mas em nenhum momento isso ocasionou algum tipo de empecilho para a realização da pesquisa e minha estadia em campo, sempre ouvi e escutei o Sandro com respeito e nunca desmerecendo o conhecimento que ele possuía, ainda que este em algum momento, se mostrasse de maneira distinta da qual eu pensava.

Desde a primeira observação (25 de maio de 2017) até finalização da pesquisa com as entrevistas (11 de novembro de 2018), eu mantinha e mantenho contato com alguns dos interlocutores. Nesse tempo, de mais de um ano, criamos uma relação, em momentos de sociabilidade do grupo, quando eu era concebido e direcionado por alguns como "amigo", sendo convidado para almoço e jantares em suas casas. Das vezes que dialogamos e compartilhamos risos e alegrias tomando chimarrão, das vezes que jogamos inúmeras partidas de "uno"31 em que os ouvia falar de seus planos e projetos de vida, onde em muitas dessas partidas eles pediam minha opinião sobre seus dilemas ou que eu me posicionasse sobre assuntos diversos (viagens, política, religião, ciência, etc.).

O Sandro, por vezes, viu na minha figura de pesquisador a possibilidade de um importante aliado e apoio e de divulgação do grupo: “divulga lá na faculdade para os

\footnotetext{
${ }^{31}$ O UNO é um jogo de cartas de baralho que sempre foi utilizado após o culto, como um momento de sociabilidade, interação e descontração entre os frequentadores. $\mathrm{O}$ jogo corriqueiramente era utilizado na sala do Pastor da Célula e contava com a presença de quatro ou seis jogadores.
} 
Religare, ISSN: 19826605, v.16, n.2, dezembro de 2019, p.461-493.

teus amigos" dizia ele. Da melhor forma possível, eu sempre deixava claro que meu comprometimento naquele momento era com a pesquisa e que os desdobramentos dela é que poderiam gerar repercussões futuras para o grupo. Caso semelhante aconteceu com Natividade (2008) e Weiss de Jesus (2012) em seus trabalhos de campo em igrejas inclusivas.

Antes do termino da pesquisa perguntava-me: o que vai ser depois de finalizar esta etapa da pesquisa? Será que ainda teremos contato? Ou meus interlocutores ficarão engavetados só vindos a serem lembrados quando essa pesquisa sair de algum lugar empoeirado, ou de uma pesquisa rápida na internet por alguns "privilegiados" academicistas? E minha resposta era: “Ainda quero continuar mantendo contato com eles".

Não trato aqui de romantizar a relação entre pesquisador e pesquisado, trata-se antes de tudo de seres humanos, pessoas que abrem espaços de suas vidas e intimidades, e que inconsciente ou conscientemente se nutre por elas algum tipo de sentimento. Durante algum tempo eu fiz parte, de alguma forma, da vida daquelas pessoas, principalmente das que frequentavam com mais regularidade os cultos. Participei e fui informado de eventos importantes para o grupo e seus familiares como: “O arraial Gospel”, "o retiro espiritual" e "O aniversário da célula”, bem como, de todos os rituais realizados no grupo.

Esses compartilhamentos de vivências e interações com as pessoas do grupo se deram a partir de relações de trocas mútuas e de negociações sociais entre mim e eles, onde eu respeitava todos os limites que me eram colocados. Isso fez com que em certa medida estabelecêssemos uma relação de confiança, fatos que me permitiram fazer parte das experiências cotidianas do grupo. Estas experiências só se tornaram possíveis por meio da etnografia e observação participante que se tornaram importante ferramenta de análise para a compreensão das minhas impressões e percepções sobre o grupo. Nesse sentido, recordava-me da importância que Weber e Beaud concediam sobre a observação e do ponto de vista empírico para a apreensão do social (WEBER \& BEAUD, 2014), também do trabalho de Weiss de Jesus (2012) que 
Religare, ISSN: 19826605, v.16, n.2, dezembro de 2019, p.461-493.

revelava a importância do tempo passado no campo de pesquisa e das relações e vivências com os interlocutores. Sem dúvidas eu fui afetado, permiti-me em alguns momentos ritualísticos ser tomado por todas as experiências e emoções vividas em campo. Assim como, Jane Favret-Saada (2005) que permitiu-se ser afetada pela "feitiçaria" em seu campo de investigação. Deixar-se ser afetado, para autora:

Como se vê, quando um etnógrafo aceita ser afetado, isso não implica identificar-se com o ponto de vista nativo, nem aproveitar-se da experiência de campo para exercitar seu narcisismo. Aceitar ser afetado supõe, todavia, que se assuma o risco de ver seu projeto de conhecimento se desfazer. Pois se o projeto de conhecimento for onipresente, não acontece nada. Mas se acontece alguma coisa e se o projeto de conhecimento não se perde em meio a uma aventura, então uma etnografia é possível (FAVRET-SAADA, 2005, p, 160).

Em alguns cultos permitia-me ser afetado, deixava as emoções tomarem conta de mim naquelas orações que eram feitas com fervor pelos frequentadores, pelos louvores cantados em vozes altas e emocionadas, deixei-me ser protegido pelo "óleo ungido", partilhando da "Santa Ceia", realizando pedidos na "fogueira santa" e atingido pelas palavras inspiradoras proferidas pelo Sandro.

Em algumas ocasiões, evitava fazer anotações em campo, chegava em casa e colocava todos esses sentimentos e percepções posteriores em um diário de campo que eu mantinha. Diário este no qual escrevia com detalhes todos os acontecimentos ocorridos durante o dia de pesquisa. Anotações estas que em seguida faziam-me compreender muitos questionamentos dos imponderáveis da vida real que este trabalho coloca (BEAUD \& WEBER, 2014; MALINOWSKI 1976; CAVEDON, 1999; FAVRET-SAADA, 2005; WHYTE, 2005).

Compartilho ainda com o leitor que no decorrer da realização da pesquisa eu estive sujeito ao processo de conversão, embora, de forma muito sutil por parte do presbítero Sandro. O fato de eu estar frequentando regularmente o culto aos domingos e fazer-me presente nos eventos do grupo fizeram o Sandro articular, mecanismos de pertencimento ou até mesmo, por vezes dizendo "daqui a pouco tu se converte" ou em outras ocasiões falando aos outros frequentadores "o pesquisador vem mais que 
Religare, ISSN: 19826605, v.16, n.2, dezembro de 2019, p.461-493.

os fiéis, já é um membro". O sentimento de uma tentativa de conversão também foi sentido por Weiss de Jesus (2012) quando etnógrafou a igreja inclusiva Metropolitana no Rio de Janeiro.

Essa ideia da conversão dava-se principalmente: 1) por eu ser um cristão, porém, não vinculado a nenhuma denominação religiosa (como o Sandro dizia: “uma ovelha desgarrada"); 2) por eu ser jovem e homossexual e por ter levado em alguns cultos meu namorado na época, que tinha curiosidade em conhecer o grupo - e tudo isto atrelado à ideia que ele tinha construído acerca da minha trajetória religiosa, de que eu poderia ser um gay cristão que sofreu dilemas com relação às questões da religião e homossexualidade.

Constatei então, que a rememoração de um passado conflituoso ou de uma circunstância difícil, de problemas pessoais parecia ser um fator interessante que o Sandro acionava para uma tentativa de conversão. Por fazer parte do movimento religioso pentecostal, o Sandro buscava analisar as trajetórias individuais dos frequentadores e o conjunto de símbolos que fizeram parte de suas experiências passadas para acionar o mecanismo de conversão. Ele via um ponto de continuidade entre o antigo e o novo; um ponto de ruptura que estava atrelado às questões da homossexualidade e o distanciamento de espaços religiosos cristãos tradicionais, elementos que se tornavam importantes no processo de conversão para uma igreja inclusiva pentecostal, porém, ainda não eficaz, se tratando do grupo em Pelotas (MAFRA, 2000).

Além disso, durante algum tempo ou como aconteceram em alguns encontros, eu era entrevistado pelos interlocutores. Indagado, questionado. Afinal, eu lhes causava algum estranhamento, assim como eles causavam a mim também. Dessa forma, o método etnográfico e observação participante auxiliaram-me a compreender, a me aproximar dos interlocutores e tornar aquilo que era estranho em familiar (WEBER \& BEAUD, 2014).

Em nenhum momento houve qualquer tipo de resistência com a minha presença em campo. Do primeiro ao último contato ocorreram algumas negociações, 
Religare, ISSN: 19826605, v.16, n.2, dezembro de 2019, p.461-493.

como, por exemplo, o uso de câmera fotográfica e o cuidado para não fotografar e nem comentar sobre o nome de alguns frequentadores que ainda não eram "assumidos" publicamente homossexuais (WEBER \& BEAUD, 2014).

\section{Conclusão}

Sendo fruto de um árduo trabalho etnográfico e de observação participante de um pouco mais de um ano, esta pesquisa, desde primeiro contato com o grupo da Comunidade Cristã Nova Esperança de Pelotas até sua finalização, contribuiu antes de tudo para meu amadurecimento (cientifico) enquanto pesquisador. No sentido que fez-me compreender como se conduz uma investigação desta natureza cientifica - a etnografia. A pesquisa também me motivou a continuar meus estudos a partir de abordagens interdisciplinares, acreditando que um projeto de conhecimento é possível a partir da reconstrução e de diálogos compartilhados com outras disciplinas. Esse trabalho contribuiu ainda para que eu pudesse ter a noção da complexidade que é a concretização de um estudo científico quando envolvem o contato direto entre pesquisador e pessoas pesquisadas. O tempo passado com o grupo e as interações em campo fizeram-me entender que eu não fazia parte do grupo, mas, ao mesmo tempo, não me isentava de sentir e viver as emoções que o campo apresentava.

A pesquisa, no sentido de adentrar o campo, não teve dificuldades; o processo de negociação e renegociação desde o início deram-se de forma harmônica entre mim e as pessoas pesquisadas, tudo isso graças, em grande parte, a flexibilidade, empatia e alteridade entre as pessoas envolvidas. Eventuais dificuldades surgiram quando via meu projeto de conhecimento ruir e ficava um tanto quanto desnorteado, principalmente quando me via diante de fatos e situações que teorias e conceitos não davam conta de explicar em relação à realidade empírica do microcosmo social investigado - fazendo com que eu visse meu projeto de conhecimento desmoronar. Além disso, diversas vezes precisei mudar posturas teóricas e conceituais. Concluía, entretanto, que determinadas teorias e conceitos não são capazes de dar conta da complexidade das relações sociais que se operam em determinados contextos micro 
Religare, ISSN: 19826605, v.16, n.2, dezembro de 2019, p.461-493.

sociais. É necessário abrir mão das generalizações para entender realidades específicas, em contextos e locais específicos quando envolvem ações de indivíduos singulares. Utilizar a etnografia como recurso metodológico fez-me ver de perto as vivências e aspectos particulares do grupo religioso pesquisado na cidade de Pelotas.

\section{Referências}

ALMEIDA, M. V. de. Senhores de si: Uma interpretação antropológica da masculinidade. 2a ed. Lisboa: Fim de Século, 2000.

ALMEIDA, R. MONTERO, Paula.Trânsito Religioso no Brasil. Revista São Paulo em Perspectiva, São Paulo, v. 15, no. 3, 2001, p. 17-35.

ALMEIDA, RONALDO. Religião na metrópole paulista. In: Revista Brasileira de Ciências Sociais, vol. 19, n. 56, out., São Paulo, ANPOCS, 2004.

ALMEIDA, RONALDO DE \& MONTEIRO, PAULA. Trânsito religioso no Brasil. São Paulo Perspec. [online]. vol.15, n.3, pp.92-100, 2001.

ALVES, Zedequias. Religião e Sexualidade: reflexões sobre igrejas inclusivas na cidade de São Paulo. Dissertação (Mestrado em Ciência da Religião). Universidade Presbiteriana Mackenzie, São Paulo, 2009.

ANGROSINO, Michel. Etnografia e observação participante. ARTMED EDITORAS. A. Tradução, José Fonseca, 2009.

BEAUD, Stéphane; WEBER, Florence. Guia para a pesquisa de campo. Produzir e analisar dados etnográficos. Petrópolis, RJ: Vozes, 2014.

BECKER, Howard S. Outsiders. Estudos de sociologia do desvio. Rio de Janeiro: Zahar, 2008.

BOURDIEU, Pierre. A distinção: crítica social do julgamento. São Paulo: Edusp; Porto Alegre, RS: Zouk, 2011.

BUTLER, Judith. Problemas de Gênero. Rio de Janeiro: Editora Record, 2003.

CAVEDON, N. R. O método etnográfico em estudos sobre cultura organizacional. In: Encontro Anual da Associação Nacional de Programas de Pós- Graduação em Adm.1999, Foz do Iguaçu. Anais, Foz do Iguaçu: ANPAD, 1999. 
Religare, ISSN: 19826605, v.16, n.2, dezembro de 2019, p.461-493.

COELHO JÚNIOR, Carlos Lacerda. "Somos ovelhas coloridas do senhor" Uma análise sociológica acerca da vivência homossexual em uma igreja inclusiva. Dissertação (Mestrado em Sociologia). Universidade Federal de Alagoas. Instituto de Ciências Sociais. Programa de Pós-Graduação em Sociologia. Maceió, 2014.

. "A emergência de uma Teologia Queer - Uma breve análise sobre as influências do movimento feminista e homossexual no processo de reconfiguração do sagrado" 17 Encontro Nacional da Rede Feminista e Norte e Nordeste de Estudos e Pesquisa sobre a Mulher e Relações de Gênero, 2012.

DURKHEIM, Emille. As Formas Elementares da Vida Religiosa. São Paulo: Martins Fontes, 2003.

GOFFMAN, E. Estigma: notas sobre a manipulação da identidade

deteriorada. Márcia Bandeira de Mello Leite Nunes (Trad.). Rio de Janeiro: LTC. 1975.

JESUS, Fátima Weiss de. Notas sobre religião e (homo) sexualidade:

'igrejas gays' no Brasil. Porto Seguro: Trabalho apresentado na 26a Reunião

Brasileira de Antropologia. 2008.

. “UNINDO A CRUZ E O ARCO-ÍRIS: Vivência Religiosa, Homossexualidades e Trânsitos de Gênero na Igreja da Comunidade Metropolitana de São Paulo". Tese (Doutorado). Universidade Federal de Santa Catarina. Programa de Pós-Graduação em Antropologia Social. Centro de Filosofia e Ciências Humanas, 2012.

MAFRA, Clara. Números e Narrativas. Os evangélicos. Rio de Janeiro: Jorge Zahar Editor. 2001.

. Relatos Compartilhados: Experiências de Conversão ao Pentecostalismo entre Brasileiros e Portugueses. Mana 6 (1):57-86, 2000.

MAFRA, Clara; ALMEIDA, Ronaldo (orgs.). Religiões e cidades: Rio de Janeiro e São Paulo. São Paulo: Editora Terceiro Nome, 2009. (Antropologia Hoje).

MAGNANI, José Guilherme Cantor. Quando o campo é a cidade: fazendo antropologia na metrópole.In: José Guilherme Cantor Magnani; Lilian de Lucca Torres. (Orgs.). Na Metrópole: Textos de Antropologia Urbana. $2^{\circ}$ edição, São Paulo: Edusp FAPESP, 1996 (2000)

MANZINI, E. J. A entrevista na pesquisa social. Didática, São Paulo, v. 26/27, p. 149-158, 1990/1991. 
Religare, ISSN: 19826605, v.16, n.2, dezembro de 2019, p.461-493.

MALINOWSKI, Bronislaw. Argonautas do pacifico ocidental: Um relato do empreendimento e da aventura dos nativos nos arquipélagos da Nova Guiné Melanésia. São Paulo: Abril Cultural, 1976. 436 p. (Pensadores (os); v.43).

MARANHÃO F. Eduardo Meinberg de Albuquerque. "Uma Igreja dos Direitos Humanos" onde "promíscuo é o indivíduo que faz mais sexo que o invejoso e inveja é pecado": Notas sobre a identidade religiosa da Igreja da Comunidade Metropolitana (ICM). Mandrágora, SBC, v.21. n. 2, p. 5-37, 2015.

. "Jesus me ama no darkroom e quando faço programa": narrativas de um reverendo e três irmãos evangélicos acerca da flexibilização do discurso religioso sobre sexualidade na Igreja da Comunidade Metropolitana. Polis e Psique, P Alegre, v. 1, n. 3, p. 221-253, 2011.

. Teologia queer e cristrans: Transições teológicas na Igreja da

Comunidade Metropolitana (ICM). Mandrágora, v.22. n. 2, p. 149-193, 2016.

MARIANO, Ricardo Neopentecostais: sociologia do novo pentecostalismo no Brasil. São

Paulo: Loyola, 1999.

MUSSKOPF, André S. A Teologia que sai do Armário: um depoimento teológico. Revista Impulso, v. 14, n.34, p. 129-146, 2003.

NATIVIDADE, Marcelo Tavares. Uma homossexualidade santificada? Etnografia de uma Comunidade inclusiva pentecostal. In: Religião e Sociedade, vol.30 n.2, Rio de Janeiro, p.90-121, 2010. Disponível em: <http://dx.doi.org/10. 1590/S0100$85872010000200006>$. Acesso em 08 de setembro 2017.

. Deus me aceita como sou? A disputa sobre o significado da homossexualidade entre evangélicos no Brasil. Tese (Doutorado em Sociologia e Antropologia). Rio de Janeiro: IFICS/UFRJ, 2008.

OLIVEIRA, Roberto Cardoso. O Trabalho do Antropólogo: Olhar, Ouvir, Escrever. In. Revista de Antrropologia , São P Aulo, USP, 1996 , v. 39 no 1.

OLIVEIRA, Pedro Paulo Martins de. A construção social da masculinidade. Belo Horizonte: UFMG/ Rio de Janeiro: IUPERJ, 2004.

PASSOS, João Décio. Pentecostais: origens e começos. São Paulo: Paulinas, 2005.

REIS, M. V. F.; SARDINHA, Antonio Carlos; Rocha, J. C.; CARMO, A. T. A 
Implantação da Igreja Inclusiva no Amapá: a homossexualidade, a fé e o acesso ao divino. In: http://www.gper.com.br/noticias/189e1950fd58e30034e00730c38e9255.pdf, p.289- 306. Acesso 06 de setembro de 2017.

RODRIGUES, E. L. Igrejas Evangélicas Inclusivas das cidades de São Paulo e Guarulhos: Um estudo pscicológicos das igrejas vistas por seus pastores. (Dissertação de Mestrado). Programa de Pós-Graduação em Psicologia, PUC, São

Paulo, 2009.

TRIVIÑOS, A. N. S. Introdução à pesquisa em ciências sociais: a pesquisa qualitativa em educação. São Paulo: Atlas, 1987.

TURNER, Victor. O processo ritual: estrutura e anti-estrutura. Petrópolis: Vozes, 1974. Floresta dos símbolos: aspectos do ritual Ndembu. Niterói: EdUFF, 2005.

VAN GENNEP, Arnold. Os Ritos de Passagem. Tradução Mariano Ferreira. 2 edição. Petrópolis: Vozes, 2011.

VELHO, G. Projeto e metamorfose: antropologia das sociedades complexas (3a ed.). Rio de Janeiro: Jorge Zahar Ed. 2003.

WEBER, Max. A Ética Protestante e o Espírito do Capitalismo. São Paulo: Martin Claret, 2003.

WHYTE, William Foote. Sociedade de esquina: a estrutura social de uma área urbana pobre e degradada. Tradução de Maria Lucia de Oliveira. Rio de Janeiro, Jorge Zahar, 2005.

\section{Referências de Site da Internet}

\section{CCNEI}

http://www.ccnei.org/ . Acesso em 10 de outubro de 2017.

Acesso em 10 de outubro de 2017.

CCNEI PASTOR JUSTINO

http://ccnei.org/pastor-justino/. Acesso em 22 de setembro de 2018.

CIDADES IBGE

https://cidades.ibge.gov.br/brasil/rs/pelotas/panorama . Acesso em 06 de setembro de 2018 
Religare, ISSN: 19826605, v.16, n.2, dezembro de 2019, p.461-493.

\section{DIÁRIO POPULAR PELOTAS}

https://www.diariopopular.com.br/geral/pastor-cria-igreja-voltada-ao-publico-gayem-

pelotas- 104860/?. Acesso em 29 de agosto de 2018.

\section{G1 GLOBO}

http://g1.globo.com/rs/rio-grande-do-sul/noticia/2012/03/expulso-por-ser-gay-pastorcria-igreja-voltada-homossexuais-no-rs.html. Acesso em 30 de janeiro de 2018.

\section{GAUCHAZH}

https://gauchazh.clicrbs.com.br/porto-alegre/noticia/2019/01/igreja-anglicana-celebraprimeiro-casamento-gay-no-rs. Acesso em 30 de janeiro de 2019.

\section{IBGE}

http://cidades.ibge.gov.br/xtras/perfil.php?codmun=160030. Acesso em 10 de outubro de 2017.

Recebido em:15-08-2019 Aprovado em: 27-12-2019 